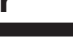

\title{
Triggering of Eryptosis, the Suicidal Erythrocyte Death by Mammalian Target of Rapamycin (mTOR) inhibitor Temsirolimus
}

\author{
Abdulla Al Mamun Bhuyan ${ }^{\mathrm{a}}$ Hang Cao ${ }^{\mathrm{a}}$ Florian Lang ${ }^{\mathrm{b}, \mathrm{c}}$ \\ aDepartment of Internal Medicine III, ${ }^{b}$ Department of Physiology I, Eberhard-Karls-University of \\ Tuebingen, Tuebingen, 'Department of Molecular Medicine II, Medical Faculty, Heinrich Heine \\ University, Duesseldorf, Germany
}

\section{Key Words}

Phosphatidylserine $\bullet$ Eryptosis $\bullet$ Staurosporine $•$ Oxidative stress $・$ Calcium $\bullet$ Ceramide

\begin{abstract}
Background/Aims: The mammalian target of rapamycin (mTOR) inhibitor temsirolimus is utilized for the treatment of malignancy. Temsirolimus is at least in part effective by triggering suicidal tumor cell death. The most common side effect of temsirolimus treatment is anemia. At least in theory, the anemia following temsirolimus treatment could result from stimulation of eryptosis, the suicidal erythrocyte death. Hallmarks of eryptosis include cell shrinkage and cell membrane scrambling with phosphatidylserine translocation to the erythrocyte surface. Signaling involved in the orchestration of eryptosis include increase of cytosolic $\mathrm{Ca}^{2+}$ activity $\left(\left[\mathrm{Ca}^{2+}\right]_{\mathrm{i}}\right)$, oxidative stress, ceramide, as well as activation of staurosporine and chelerythrine sensitive protein kinase C, SB203580 sensitive p38 kinase, D4476 sensitive casein kinase 1, and zVAD sensitive caspases. The purpose of the present study was to test whether temsirolimus influences eryptosis and, if so, to shed light on the signaling involved. Methods: Flow cytometry was employed to estimate cell volume from forward scatter, phosphatidylserine exposure at the cell surface from annexin-V-binding, $\left[\mathrm{Ca}^{2+}\right]_{i}$ from Fluo3-fluorescence, reactive oxygen species (ROS) abundance from DCFDA dependent fluorescence, and ceramide abundance utilizing specific antibodies. Hemolysis was determined from hemoglobin concentration in the supernatant. Results: A 48 hours exposure of human erythrocytes to temsirolimus (5 $20 \mu \mathrm{g} / \mathrm{ml}$ ) significantly decreased forward scatter and significantly increased the percentage of annexin-V-binding cells. Temsirolimus significantly increased Fluo3-fluorescence, DCFDA fluorescence and ceramide abundance at the erythrocyte surface. The effect of temsirolimus on annexin-V-binding was significantly blunted but not abolished by removal of extracellular $\mathrm{Ca}^{2+}$ and by addition of staurosporine $(1 \mu \mathrm{M})$ or chelerythrine $(10 \mu \mathrm{M})$ but not significantly modified by addition of SB203580 $(2 \mu \mathrm{M})$, D4476 $(10 \mu \mathrm{M})$, or zVAD $(10 \mu \mathrm{M})$. Chelerythrine $(10 \mu \mathrm{M})$ further significantly blunted the effect of temsirolimus on DCFDA fluorescence but not ceramide formation. Removal of extracellular $\mathrm{Ca}^{2+}$ had no effect on temsirolimus induced ROS formation or ceramide abundance. Conclusions: Temsirolimus triggers eryptosis with
\end{abstract}

A. Al Mamun Bhuyan and $\mathrm{H}$. Cao contributed equally and thus share first authorship.

\begin{tabular}{ll}
\hline Florian Lang & $\begin{array}{l}\text { Department of Physiology I, University of Tuebingen, Gmelinstr. 5, } 72076 \text { Tuebingen } \\
\text { (Germany) } \\
\text { Tel. +49 } 7071 \text { 29-72194, Fax +49 } 7071 \text { 29-5618, E-Mail florian.lang@uni-tuebingen.de }\end{array}$ \\
&
\end{tabular}


cell shrinkage and phospholipid scrambling of the erythrocyte cell membrane, an effect at least in part due to $\mathrm{Ca}^{2+}$ entry, oxidative stress, ceramide and activation of staurosporine/ Chelerythrine sensitive kinase(s).

\section{Introduction}

Temsirolimus, an ester derivative of sirolimus (rapamycin) and selective inhibitor of the kinase mammalian target of rapamycin (mTOR) [1-9], is a cytostatic drug widely used in the treatment of diverse malignancies including refractory mantle cell lymphoma [1,10-15], non-Hodgkin lymphomas $[15,16]$, multiple myeloma [16], metastatic renal cell carcinoma $[2,17-44]$, and a variety of further solid tumors $[16,45,46]$.

Temsirolimus is effective by inducing apoptosis of tumor cells [9, 47-57]. Signaling involved includes activation of caspases [47]. On the other hand temsirolimus may counteract apoptosis of hippocampal neurons [58]. The most common side effects of temsirolimus include the development of anemia $[59,60]$.

The anemia could result from suicidal death of erythrocytes or eryptosis [61], which is characterized by cell membrane scrambling with phosphatidylserine translocation to the cell surface [61]. Following most stimulators of eryptosis, the cell membrane scrambling is paralleled by cell shrinkage [62]. During eryptosis, the cell membrane typically remains tight thus preventing cellular release of hemoglobin with subsequent glomerular filtration and tubular precipitation of hemoglobin, occlusion of nephrons and renal injury [63]. Necroptosis-like suicidal erythrocyte death disrupts the cell membrane integrity by plasma membrane pore formation [64].

Signaling participating in the orchestration of eryptosis include increase of cytosolic $\mathrm{Ca}^{2+}$ activity $\left(\left[\mathrm{Ca}^{2+}\right]_{\mathrm{i}}\right)[61]$, ceramide [65], caspases [61, 66, 67], G-protein Galphai2 [68], casein kinase $1 \alpha$ [69], Janus-activated kinase JAK3 [70], protein kinase C [71], and p38 kinase [72]. Eryptosis is suppressed by AMP activated kinase AMPK [73], cGMP-dependent protein kinase [74], mitogen and stress activated kinase MSK1/2 [75], PAK2 kinase [76] and sorafenib/sunitinib sensitive kinases $[77,78]$. Eryptosis is triggered by a wide variety of conditions including hyperosmotic shock [61], oxidative stress [61], energy depletion [61], or exposure to diverse xenobiotics [61,79-137]. Several clinical disorders are associated with enhanced eryptosis, such as iron deficiency [61], dehydration [138], hyperphosphatemia [139], chronic kidney disease (CKD) [140-143], hemolytic-uremic syndrome [144], diabetes [145], hepatic failure [79], malignancy [146, 147], arteriitis [148], sepsis [149], sickle-cell disease [61], beta-thalassemia [61], Hb-C and G6PD-deficiency [61], Wilsons disease [149], as well as advanced age [150]. Eryptosis further increases following storage of blood for transfusion [151].

The present study explored, whether temsirolimus modifies eryptosis. To this end, human erythrocytes from healthy volunteers were exposed to temsirolimus and phosphatidylserine surface abundance, cell volume, $\left[\mathrm{Ca}^{2+}\right]_{i}$, ROS formation, and ceramide abundance determined by flow cytometry.

\section{Materials and Methods}

Erythrocytes, solutions and chemicals

Fresh Li-Heparin-anticoagulated blood samples were kindly provided by the blood bank of the University of Tübingen. The study is approved by the ethics committee of the University of Tübingen $(184 / 2003 \mathrm{~V})$. The blood was centrifuged at $120 \mathrm{~g}$ for $20 \mathrm{~min}$ at $21{ }^{\circ} \mathrm{C}$ and the platelets and leukocytes-containing supernatant was disposed. Erythrocytes were incubated in vitro at a hematocrit of $0.4 \%$ in Ringer solution containing (in mM) $125 \mathrm{NaCl}, 5 \mathrm{KCl}, 1 \mathrm{MgSO}_{4}$, $32 \mathrm{~N}$-2-hydroxyethylpiperazine-N-2-ethanesulfonic acid (HEPES; pH 7.4), 5 glucose, $1 \mathrm{CaCl}_{2}$, at $37^{\circ} \mathrm{C}$ for 48 hours. Where indicated, erythrocytes were exposed for 48 hours to temsirolimus (Sigma Aldrich, Hamburg, Germany). In order to estimate the impact of $\mathrm{Ca}^{2+}$ entry on temsirolimus induced 
eryptosis, erythrocytes were exposed to temsirolimus in the presence and absence of extracellular $\mathrm{Ca}^{2+}$. To test for an involvement of kinases, erythrocytes were exposed for 48 hours to a combination of temsirolimus and p38 kinase inhibitor SB203580 (Tocris bioscience, Bristol, UK), protein kinase C inhibitor staurosporine (Enzo Life Sciences, Lörrach, Germany), specific protein kinase C inhibitor chelerythrine (Enzo Life Sciences, Lörrach, Germany) or casein kinase inhibitor D4476 (Tocris Bioscience, Bristol, UK). The impact of caspases was elucidated utilizing the pancaspase inhibitor zVAD (Enzo Life Sciences, Lörrach, Germany).

\section{Annexin-V-binding and forward scatter}

After incubation under the respective experimental condition, a $150 \mu \mathrm{l}$ cell suspension was washed in Ringer solution containing $5 \mathrm{mM} \mathrm{CaCl}_{2}$ and then stained with Annexin-V-FITC 1:200 dilution; ImmunoTools, Friesoythe, Germany) in this solution at $37^{\circ} \mathrm{C}$ for $15 \mathrm{~min}$ under protection from light. The annexin-Vabundance at the erythrocyte surface was subsequently determined on a FACS Calibur (BD, Heidelberg, Germany). Annexin-V-binding was measured with an excitation wavelength of $488 \mathrm{~nm}$ and an emission wavelength of $530 \mathrm{~nm}$. A marker (M1) was placed to set an arbitrary threshold between annexin-V-binding cells and control cells. The same threshold was used for untreated and temsirolimus treated erythrocytes. A dot plot of forward scatter (FSC) vs. side scatter (SSC) was set to linear scale for both parameters. The threshold of forward scatter was set at the default value of " 52 ".

\section{Intracellular $\mathrm{Ca}^{2+}$}

After incubation, erythrocytes were washed in Ringer solution and loaded with Fluo-3/AM (Biotium, Hayward, USA) in Ringer solution containing $5 \mathrm{mM} \mathrm{CaCl}_{2}$ and $5 \mu \mathrm{M}$ Fluo-3/AM. The cells were incubated at $37^{\circ} \mathrm{C}$ for $30 \mathrm{~min} . \mathrm{Ca}^{2+}$-dependent fluorescence intensity was measured with an excitation wavelength of $488 \mathrm{~nm}$ and an emission wavelength of $530 \mathrm{~nm}$ on a FACS Calibur. Afterwards, the geomean of the $\mathrm{Ca}^{2+}$ dependent fluorescence was determined.

\section{Reactive oxygen species (ROS)}

Oxidative stress was determined utilizing 2',7'-dichlorodihydrofluorescein diacetate (DCFDA). After incubation, a $150 \mu \mathrm{l}$ suspension of erythrocytes was washed in Ringer solution and stained with DCFDA (Sigma, Aldrich, Germany) in Ringer solution containing DCFDA at a final concentration of $10 \mu \mathrm{M}$. Erythrocytes were incubated at $37^{\circ} \mathrm{C}$ for $30 \mathrm{~min}$ in the dark and washed two times in Ringer solution. The DCFDA-loaded erythrocytes were resuspended in $200 \mu \mathrm{l}$ Ringer solution and ROS-dependent fluorescence intensity was measured at an excitation wavelength of $488 \mathrm{~nm}$ and an emission wavelength of $530 \mathrm{~nm}$ on a FACS Calibur (BD). Subsequently, the geomean of the DCFDA dependent fluorescence was determined.

\section{Ceramide abundance}

For the determination of ceramide, a monoclonal antibody-based assay was used. To this end, cells were stained for 1 hour at $37^{\circ} \mathrm{C}$ with $1 \mu \mathrm{g} / \mathrm{ml}$ anti ceramide antibody (clone MID 15B4, Alexis, Grünberg, Germany) in PBS containing $0.1 \%$ bovine serum albumin (BSA) at a dilution of $1: 10$. The samples were washed twice with PBS-BSA. The cells were stained for 30 minutes with polyclonal fluorescein isothiocyanate (FITC) conjugated goat anti-mouse IgG and IgM specific antibody (Pharmingen, Hamburg, Germany) diluted 1:50 in PBS-BSA. Unbound secondary antibody was removed by repeated washing with PBS-BSA. The samples were analysed by flow cytometry with an excitation wavelength of $488 \mathrm{~nm}$ and an emission wavelength of $530 \mathrm{~nm}$. Finally, the geomean of the ceramide-dependent fluorescence was determined.

\section{Hemolysis}

For the determination of hemolysis, the samples were centrifuged ( $3 \mathrm{~min}$. at $1600 \mathrm{rpm}$ in room temperature) after incubation, and the supernatants were harvested. As a measure of hemolysis, the hemoglobin $(\mathrm{Hb})$ concentration of the supernatant was determined photometrically at $405 \mathrm{~nm}$. The absorption of the supernatant of erythrocytes lysed in distilled water was defined as $100 \%$ hemolysis.

\section{Statistics}

Data are expressed as arithmetic means \pm SD. As indicated in the figure legends, statistical analysis was made using ANOVA with Tukey's test as post-test and $t$ test as appropriate. $\mathrm{n}$ denotes the number of different erythrocyte specimens studied. Since different erythrocyte specimens used in distinct experiments are 
differently susceptible to triggers of eryptosis, the same erythrocyte specimens have been used for control and experimental conditions.

\section{Results}

The present study explored the impact of temsirolimus on eryptosis, the suicidal erythrocyte death. Hallmarks of eryptosis include erythrocyte shrinkage and phospholipid scrambling of the cell membrane with phosphatidylserine translocation to the cell surface.

Cell volume was estimated from forward scatter determined by flow cytometry. The measurements were made after an incubation of the erythrocytes for 48 hours in Ringer solution without or with temsirolimus $(5-20 \mu \mathrm{g} / \mathrm{ml})$. As illustrated in Fig. 1, a 48 hours exposure to temsirolimus significantly decreased the forward scatter at each of the concentrations applied. It further increased the percentage of shrunken erythrocytes, an effect reaching statistical significance at $20 \mu \mathrm{g} / \mathrm{ml}$ temsirolimus. Moreover, the exposure to temsirolimus decreased the percentage of swollen erythrocytes at each of the concentrations applied.

Phosphatidylserine exposing erythrocytes were identified utilizing annexin-V-binding to phosphatidylserine, as determined by flow cytometry. Annexin-V-binding was analysed following an incubation of the erythrocytes for 48 hours in Ringer solution without or

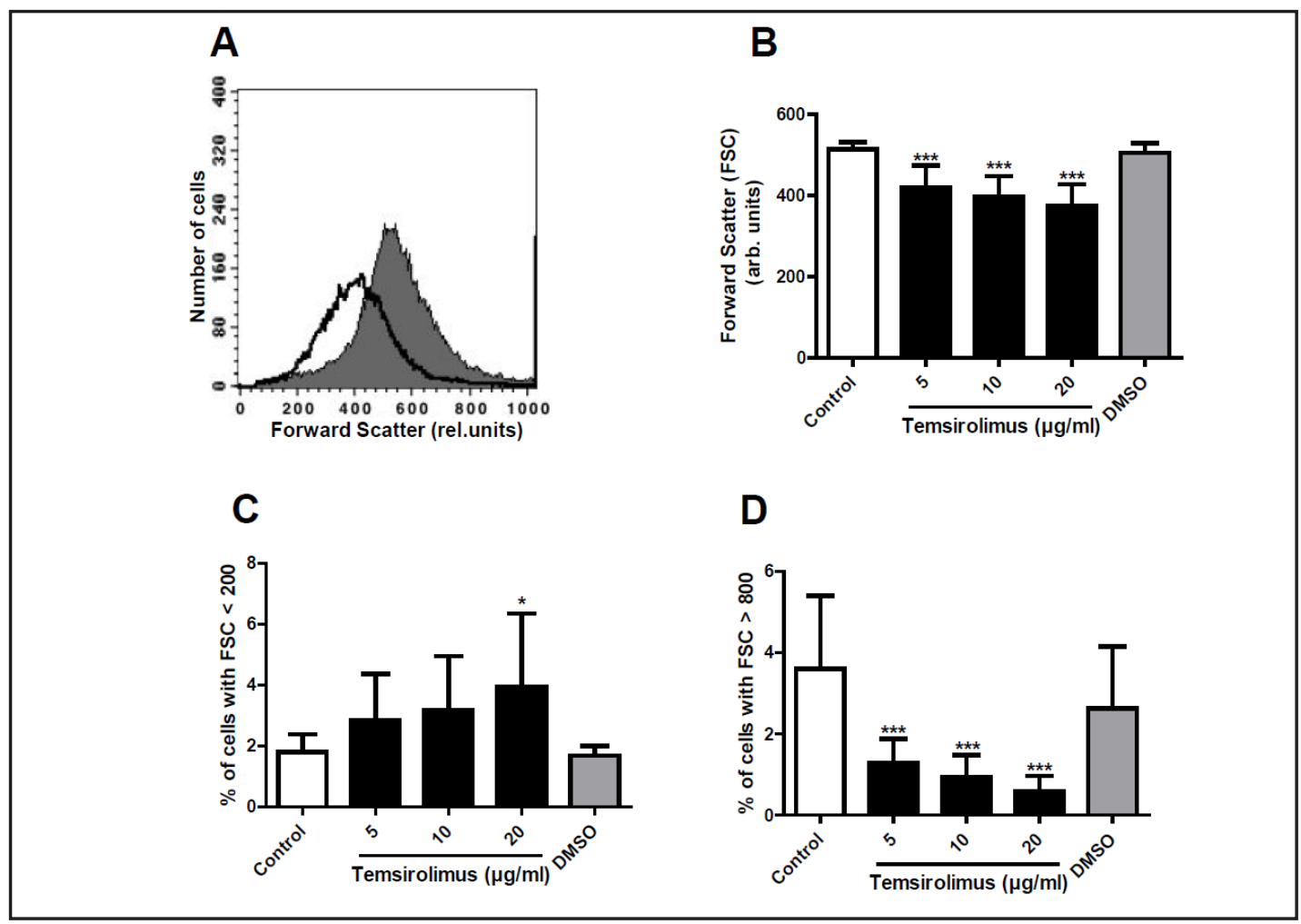

Fig. 1. Effect of Temsirolimus on erythrocyte forward scatter. A. Original histograms of forward scatter of erythrocytes following exposure for 48 hours to Ringer solution without (grey area) and with (black line) presence of $20 \mu \mathrm{g} / \mathrm{ml}$ Temsirolimus. B. Arithmetic means \pm SD $(\mathrm{n}=11)$ of the erythrocyte forward scatter (FSC) following incubation for 48 hours to Ringer solution without (white bar) or with (black bars) Temsirolimus (5 - $20 \mu \mathrm{g} / \mathrm{ml}$ ) or solvant DMSO alone (grey bar). C,D. Arithmetic means \pm SD of the percentage of erythrocytes with (C) FSC $<200$ or (D) FSC $>800$ following incubation for 48 hours to Ringer solution without (white bar) or with (black bars) Temsirolimus (5 - $20 \mu \mathrm{g} / \mathrm{ml}$ ) or solvant DMSO alone (grey bar). $*(\mathrm{P}<0.05),{ }^{* * *}(\mathrm{p}<0.001)$ indicates significant difference from the absence of temsirolimus (ANOVA). 
Fig. 2. Effect of temsirolimus on phosphatidylserine exposure. A. Original histogram of annexin-Vbinding of erythrocytes following exposure for 48 hours to Ringer solution without (grey area) and with (black line) presence of $20 \mu \mathrm{g} / \mathrm{ml}$ temsirolimus. B. Arithmetic means $\pm \mathrm{SD}(\mathrm{n}=16)$ of erythrocyte annexinV-binding following incubation for 48 hours to Ringer solution without

A

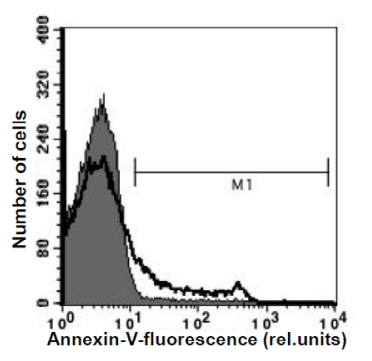

B

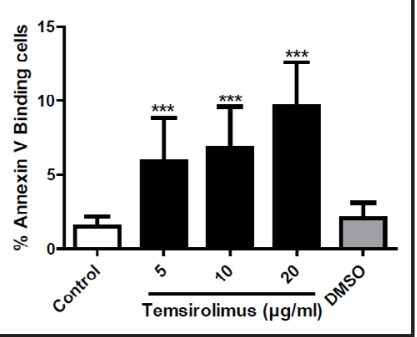

(white bar) or with (black bars) temsirolimus $(5-20 \mu \mathrm{g} / \mathrm{ml})$. For comparison, the effect of the solvent DMSO is shown (grey bar). ${ }^{* * *}(\mathrm{p}<0.001)$ indicates significant difference from the absence of temsirolimus (ANOVA).

Fig. 3. Effect of temsirolimus on cytosolic $\mathrm{Ca}^{2+}$ activity. A. Original histogram of Fluo3 fluorescence of erythrocytes following exposure for 48 hours to Ringer solution without (grey area) and with (black line) presence of $20 \mu \mathrm{g} / \mathrm{ml}$ temsirolimus. B. Arithmetic means \pm SD $(n=16)$ of erythrocyte Fluo3 fluorescence following incubation for 48 hours to Ringer solution without (white bar)

A

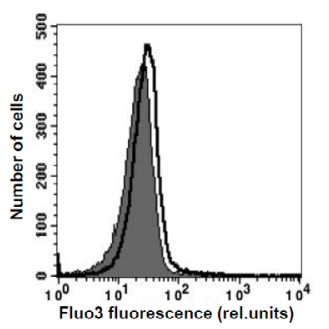

B

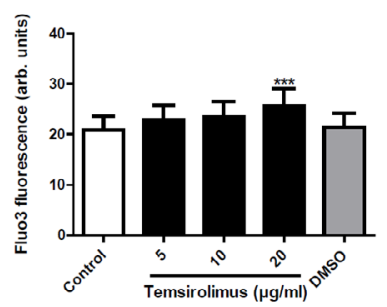

or with (black bars) temsirolimus (5 - $20 \mu \mathrm{g} / \mathrm{ml})$. For comparison, the effect of the solvent DMSO is shown (grey bar). ${ }^{* * *}(\mathrm{p}<0.001)$ indicates significant difference from the absence of temsirolimus (ANOVA).

with temsirolimus (5 - $20 \mu \mathrm{g} / \mathrm{ml})$. As shown in Fig. 2, a 48 hours exposure to temsirolimus increased the percentage of phosphatidylserine exposing erythrocytes at each of the concentrations applied.

Both, cell shrinkage and cell membrane scrambling could result from an increase of cytosolic $\mathrm{Ca}^{2+}$ activity $\left(\left[\mathrm{Ca}^{2+}\right]_{\mathrm{i}}\right)$. Fluo3 fluorescence was employed in order to quantify $\left[\mathrm{Ca}^{2+}\right]_{\mathrm{i}}$. The erythrocytes were analysed after a 48 hours incubation in Ringer solution without or with temsirolimus ( $5-20 \mu \mathrm{g} / \mathrm{ml})$. As illustrated in Fig. 3, a 48 hours exposure to temsirolimus increased the Fluo3 fluorescence, an effect reaching statistical significance at $20 \mu \mathrm{g} / \mathrm{ml}$ temsirolimus.

In order to test whether entry of extracellular $\mathrm{Ca}^{2+}$ is required for the stimulation of cell membrane scrambling by temsirolimus, erythrocytes were incubated for 48 hours in the absence or presence of $20 \mu \mathrm{g} / \mathrm{ml}$ temsirolimus in the presence or nominal absence of extracellular $\mathrm{Ca}^{2+}$. As illustrated in Fig. 4, removal of extracellular $\mathrm{Ca}^{2+}$ significantly blunted the effect of temsirolimus on annexin-V-binding. However, even in the absence of extracellular $\mathrm{Ca}^{2+}$, temsirolimus significantly increased the percentage of annexin-V-binding erythrocytes. Thus, temsirolimus triggered cell membrane scrambling in part but not exclusively by entry of extracellular $\mathrm{Ca}^{2+}$.

Eryptosis is further stimulated by oxidative stress. Reactive oxygen species (ROS) was thus quantified utilizing $2^{\prime}, 7^{\prime}$-dichlorodihydrofluorescein diacetate (DCFDA). As illustrated in Fig. 5, a 48 hours exposure to temsirolimus $(20 \mu \mathrm{g} / \mathrm{ml})$ significantly increased the DCFDA fluorescence of erythrocytes. Thus, temsirolimus does trigger oxidative stress.

A further stimulator of eryptosis is ceramide. Ceramide abundance at the erythrocyte surface was quantified utilizing specific antibodies. As shown in Fig. 6, a 48 hours exposure to temsirolimus $(20 \mu \mathrm{g} / \mathrm{ml})$ significantly increased the ceramide abundance at the erythrocyte surface. 

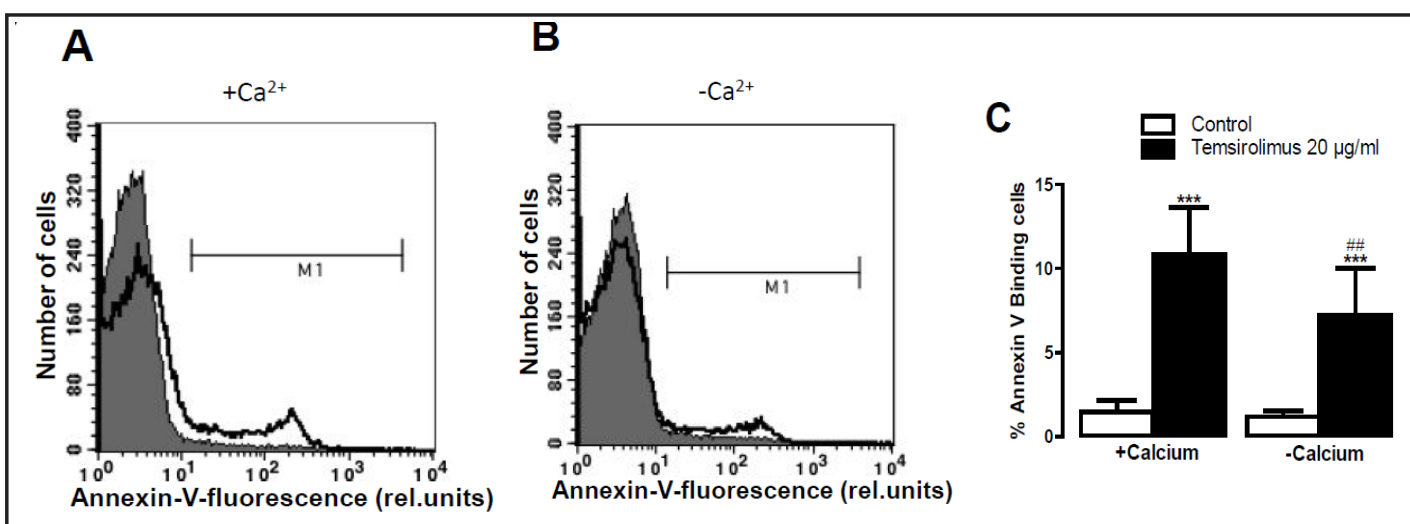

Fig. 4. $\mathrm{Ca}^{2+}$ sensitivity of temsirolimus-induced phosphatidylserine exposure. A,B. Original histograms of annexin-V-binding of erythrocytes following exposure for 48 hours to Ringer solution without (grey areas) and with (black lines) temsirolimus $(20 \mu \mathrm{g} / \mathrm{ml})$ in the presence (A) and absence (B) of extracellular $\mathrm{Ca}^{2+}$. C. Arithmetic means \pm SD $(n=8)$ of annexin-V-binding of erythrocytes after a 48 hours treatment with Ringer solution without (white bars) or with (black bars) temsirolimus $(20 \mu \mathrm{g} / \mathrm{ml})$ in the presence (left bars, $\left.+\mathrm{Ca}^{2+}\right)$ and absence (right bars, $\left.-\mathrm{Ca}^{2+}\right)$ of $\mathrm{Ca}^{2+} .{ }^{* * *}(\mathrm{p}<0.001)$ indicates significant difference from the absence of temsirolimus, \#\# $(\mathrm{p}<0.01)$ indicates significant difference from the presence of $\mathrm{Ca}^{2+}(\mathrm{ANOVA})$.

Fig. 5. Effect of temsirolimus on reactive oxygen species. A. Original histogram of DCFDA fluorescence in erythrocytes following exposure for 48 hours to Ringer solution without (grey area) and with (black line) presence of $20 \mu \mathrm{g} / \mathrm{ml}$ temsirolimus. B. Arithmetic means \pm SD $(n=8)$ of DCFDA fluorescence in erythrocytes following incubation for 48 hours to Ringer solution without (white bar)

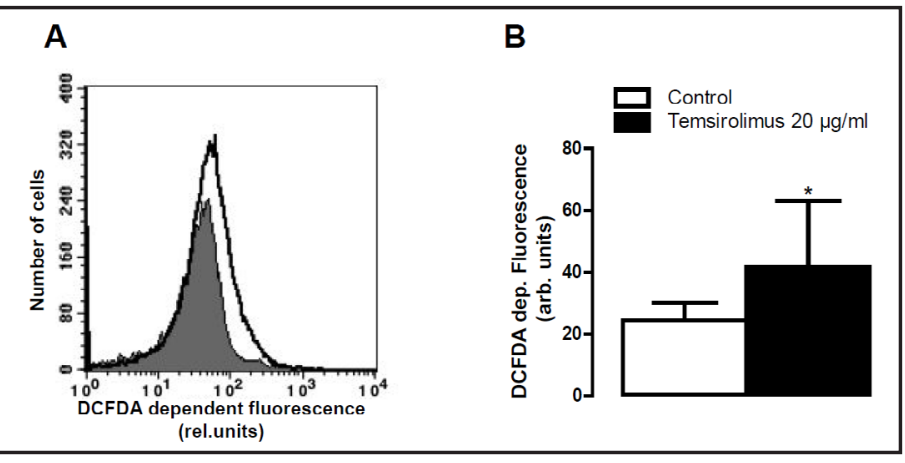
or with (black bar) temsirolimus $(20 \mu \mathrm{g} / \mathrm{ml}) .{ }^{*}(\mathrm{p}<0.05)$ indicates significant difference from the absence of temsirolimus (unpaired $t$ test).

Fig. 6. Effect of Temsirolimus on ceramide abundance. A. Original histograms of ceramide abundance at the erythrocyte surface following exposure for 48 hours to Ringer solution without (grey area) and with (black line) presence of $20 \mu \mathrm{g} / \mathrm{ml}$ Temsirolimus. B. Arithmetic means \pm SD (n $=5$ ) of ceramide abundance at the erythrocyte surface following incubation for 48 hours to Ringer solu-

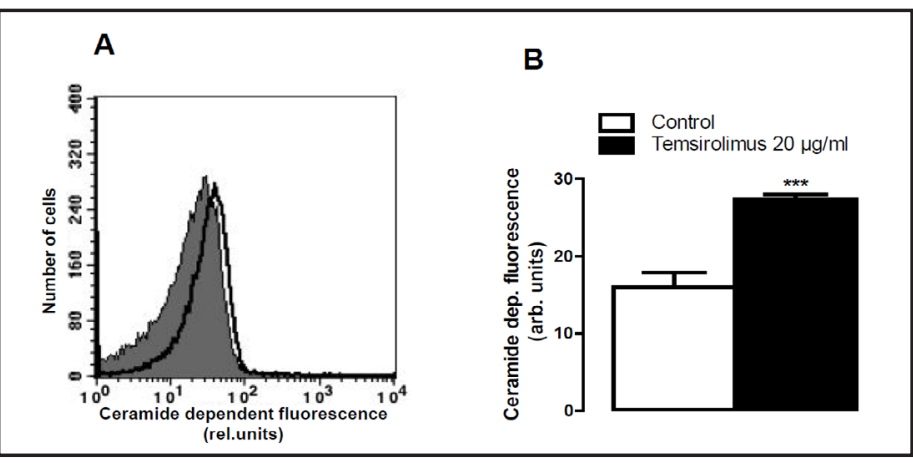
tion without (white bar) or with (black bars) Temsirolimus $(20 \mu \mathrm{g} / \mathrm{ml}) .{ }^{* * *}(\mathrm{p}<0.001)$ indicates significant difference from the absence of Temsirolimus (ANOVA).

To explore, whether the effects of temsirolimus involved kinase activity, the influence of temsirolimus on annexin-V-binding was tested in the presence of protein kinase $\mathrm{C}$ inhibitors staurosporine and chelerythrine, of p38 kinase inhibitor SB203580, or of casein kinase 1 inhibitor D4476. As illustrated in Fig. 7, staurosporine $(1 \mu \mathrm{M})$ significantly blunted the 

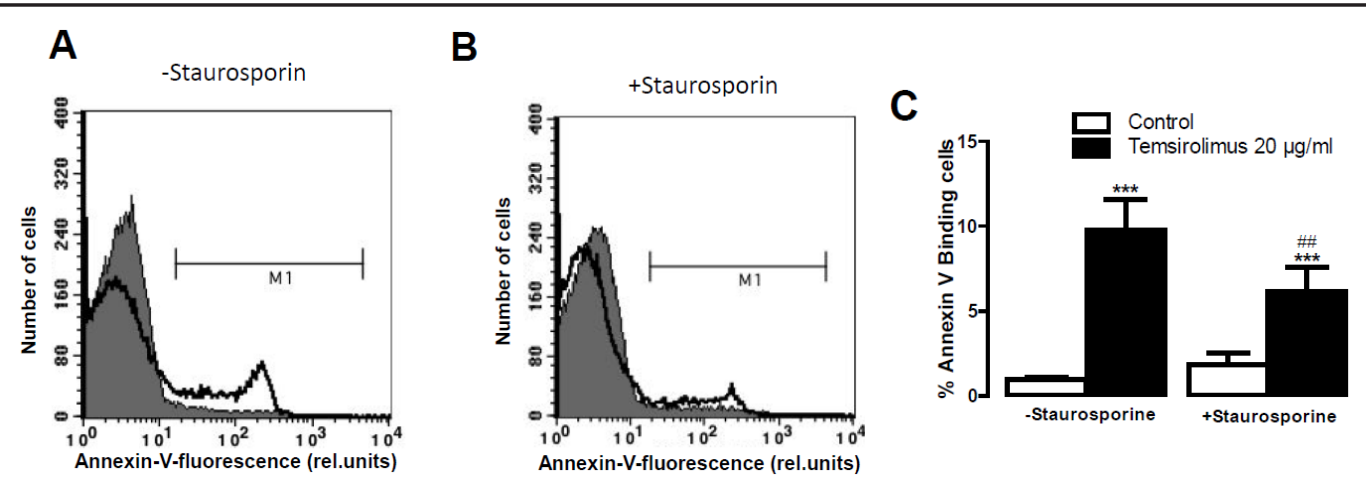

Fig. 7. Staurosporine sensitivity of temsirolimus-induced phosphatidylserine exposure. A,B. Original histograms of annexin-V-binding of erythrocytes following exposure for 48 hours to Ringer solution without (grey areas) and with (black lines) temsirolimus $(20 \mu \mathrm{g} / \mathrm{ml})$ in the absence (A) and presence (B) of protein kinase $C$ inhibitor staurosporine $(1 \mu \mathrm{M})$.C. Arithmetic means \pm SD $(n=5)$ of annexin-V-binding of erythrocytes after a 48 hours treatment with Ringer solution without (white bars) or with (black bars) temsirolimus $(20 \mu \mathrm{g} / \mathrm{ml})$ in the absence (left bars, - staurosporine) and presence (right bars, + staurosporine) of protein kinase $\mathrm{C}$ inhibitor staurosporine $(1 \mu \mathrm{M}) .{ }^{* * *}(\mathrm{p}<0.001)$ indicates significant difference from the absence of temsirolimus, \#\#( $<<0.01)$ indicates significant difference from the absence of staurosporine 1 $\mu \mathrm{M})$ (ANOVA).
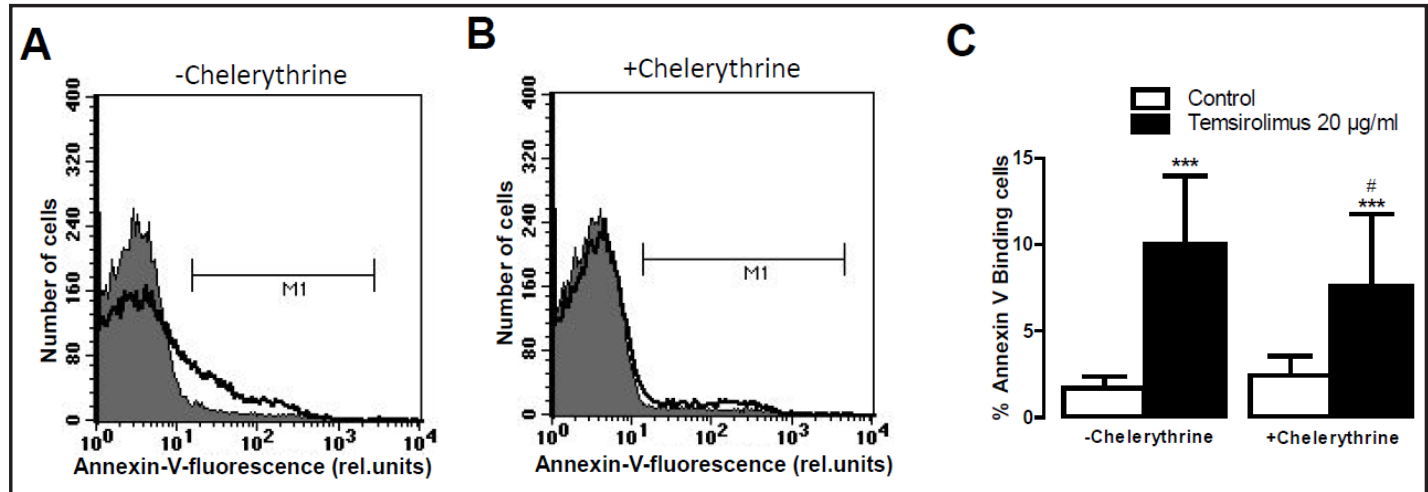

Fig. 8. Sensitivity of Chelerythrine on temsirolimus-induced phosphatidylserine exposure. A,B. Original histograms of annexin-V-binding of erythrocytes following exposure for 48 hours to Ringer solution without (grey areas) and with (black lines) temsirolimus $(20 \mu \mathrm{g} / \mathrm{ml})$ in the absence (A) and presence (B) of protein kinase C inhibitor chelerythrine $(10 \mu \mathrm{M})$. C. Arithmetic means \pm SD $(n=29)$ of annexin-V-binding of erythrocytes after a 48 hours treatment with Ringer solution without (white bars) or with (black bars) temsirolimus $(20 \mu \mathrm{g} / \mathrm{ml})$ in the absence (left bars, - chelerythrine) and presence (right bars, + chelerythrine) of protein kinase $\mathrm{C}$ inhibitor chelerythrine $(10 \mu \mathrm{M}){ }^{* * *}(\mathrm{p}<0.001)$ indicates significant difference from the absence of temsirolimus, $\#(p<0.05)$ indicates significant difference from the absence of chelerythrine $(10$ $\mu \mathrm{M})$ (ANOVA).

effect of temsirolimus $(20 \mu \mathrm{g} / \mathrm{ml})$ on annexin-V-binding. Similarly, chelerythrine $(10 \mu \mathrm{M})$ significantly blunted the effect of temsirolimus $(20 \mu \mathrm{g} / \mathrm{ml})$ on annexin-V-binding (Fig. 8). However, even in the presence of staurosporine or chelerythrine, temsirolimus significantly increased the percentage of annexin-V-binding erythrocytes. Accordingly, temsirolimusinduced cell membrane scrambling was in part but not fully dependent on staurosporine and chelerythrine sensitive kinases.

Additional experiments were performed to test whether the effects of extracellular $\mathrm{Ca}^{2+}$ removal and protein kinase $\mathrm{C}$ inhibition were additive. To this end, erythrocytes were 


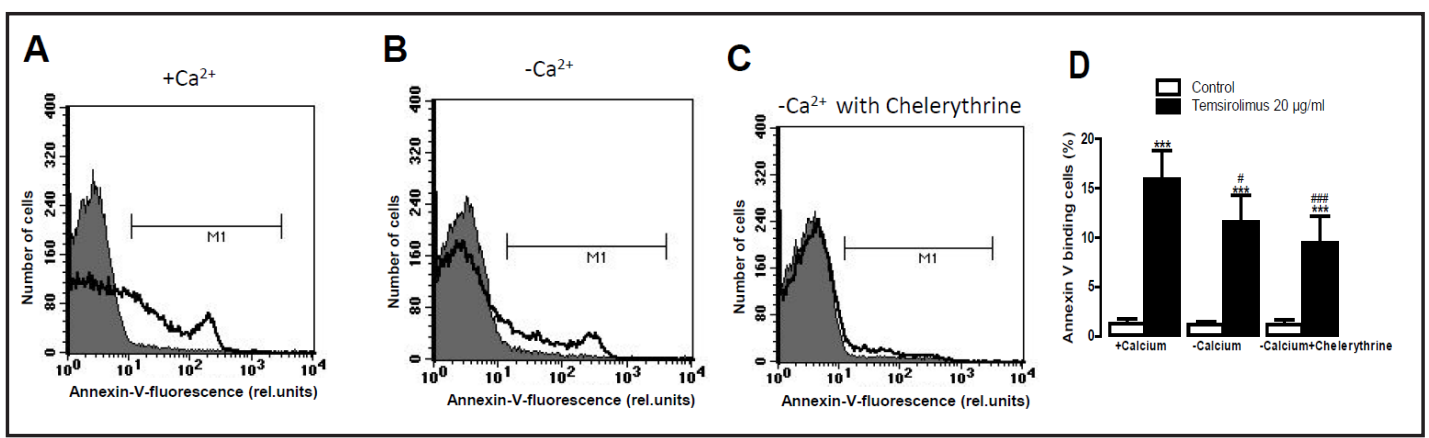

Fig. 9. Effects of $\mathrm{Ca}^{2+}$ removal without and with addition of chelerythrine on temsirolimus-induced phosphatidylserine exposure. A,B,C. Original histograms of annexin-V-binding of erythrocytes following exposure for 48 hours to Ringer solution without (grey areas) and with (black lines) temsirolimus (20 $\mu \mathrm{g} / \mathrm{ml}) \mathrm{in}$ the presence (A) and absence (B) of extracellular $\mathrm{Ca}^{2+}$ as well as (C) simultaneous absence of extracellular $\mathrm{Ca}^{2+}$ and presence of chelerythrine $(10 \mu \mathrm{M})$. D. Arithmetic means \pm SD $(n=5)$ of annexin-V-binding of erythrocytes after a 48 hours treatment with Ringer solution without (white bars) or with (black bars) temsirolimus $(20 \mu \mathrm{g} / \mathrm{ml})$ in the presence (left bars) and absence (middle bars) of $\mathrm{Ca}^{2+}$ as well as the absence (right bars) of $\mathrm{Ca}^{2}$ and presence of chelerythrine. ${ }^{* * *}(\mathrm{p}<0.001)$ indicates significant difference from the absence of temsirolimus, ${ }^{\prime}(\mathrm{p}<0.05),{ }^{\# \#}(\mathrm{p}<0.001)$ indicates significant difference from the presence of $\mathrm{Ca}^{2+}(\mathrm{ANOVA})$.

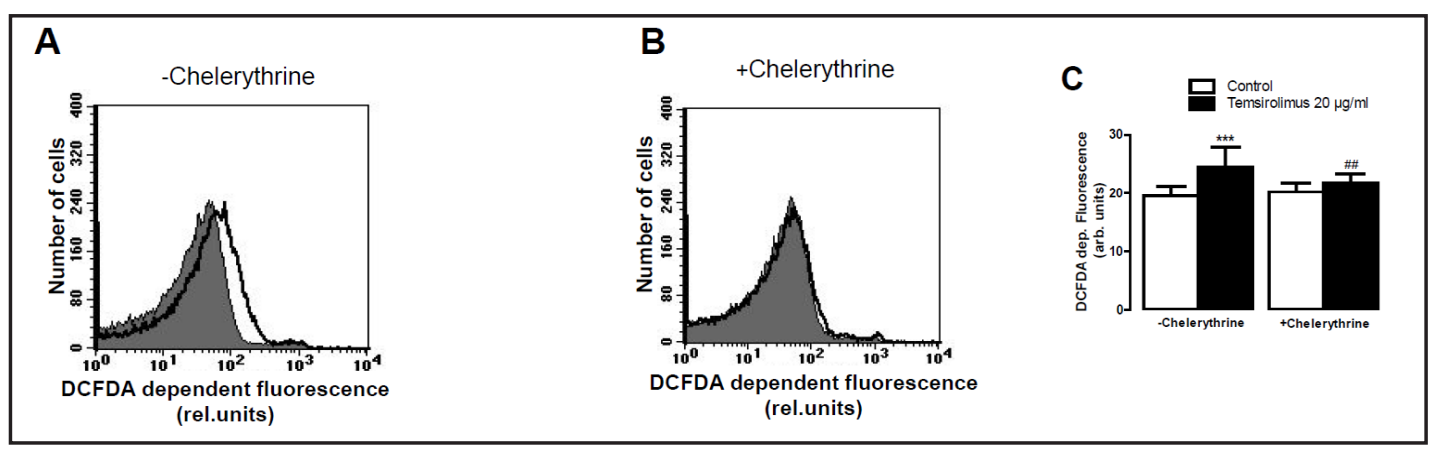

Fig. 10. Chelerythrine sensitivity of temsirolimus-induced reactive oxygen species formation. A,B. Original histogram of DCFDA fluorescence in erythrocytes following exposure for 48 hours to Ringer solution without (grey areas) and with (black lines) temsirolimus $(20 \mu \mathrm{g} / \mathrm{ml})$ in the absence (A) and presence (B) of protein kinase $C$ inhibitor chelerythrine $(10 \mu \mathrm{M})$. C. Arithmetic means \pm SD $(n=16)$ of DCFDA fluorescence in erythrocytes after a 48 hours treatment with Ringer solution without (white bars) or with (black bars) temsirolimus $(20 \mu \mathrm{g} / \mathrm{ml})$ in the absence (left bars, - Chelerythrine) and presence (right bars, + Chelerythrine) of protein kinase $C$ inhibitor Chelerythrine $(10 \mu \mathrm{M}){ }^{* * *}(\mathrm{p}<0.001)$ indicates significant difference from the absence of temsirolimus, \#\#(p<0.01) indicates significant difference from the absence of Chelerythrine $(10 \mu \mathrm{M})(\mathrm{ANOVA})$.

incubated for 48 hours in the absence or presence of temsirolimus $(20 \mu \mathrm{g} / \mathrm{ml})$ in the presence or nominal absence of extracellular $\mathrm{Ca}^{2+}$ with or without presence of chelerythrine. As illustrated in Fig. 9, the annexin-V-binding was significantly blunted by $\mathrm{Ca}^{2+}$ removal and further blunted in the additional presence of chelerythrine $(10 \mu \mathrm{M})$. However, even in the absence of extracellular $\mathrm{Ca}^{2+}$ and presence of chelerythrine temsirolimus still significantly increased cell membrane scrambling, an observation pointing to involvement of additional mechanisms.

Further experiments tested whether temsirolimus induced reactive oxygen species (ROS) formation is sensitive to extracellular $\mathrm{Ca}^{2+}$ removal and/or chelerythrine. To this end, erythrocytes were incubated for 48 hours in the absence or presence of $20 \mu \mathrm{g} / \mathrm{ml}$ temsirolimus in the absence or presence of chelerythrine $(10 \mu \mathrm{M})$ and in the presence or nominal absence 
Fig. 11. Effect of temsirolimus on hemolysis. Arithmetic means \pm SD $(n=5)$ of the percentage of hemolysed erythrocytes following incubation for 48 hours to Ringer solution without (white bar) or with (black bars) temsirolimus $(5-20 \mu \mathrm{g} / \mathrm{ml}) .{ }^{* * *}(\mathrm{p}<0.001)$ indicates significant difference from the absence of temsirolimus (ANOVA).

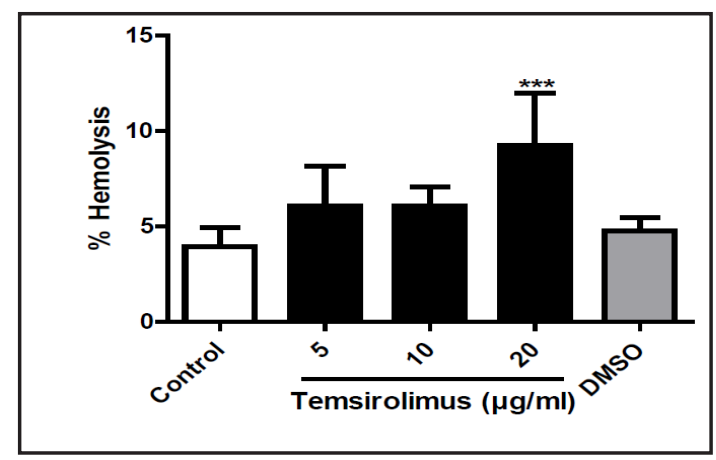

of extracellular $\mathrm{Ca}^{2+}$. As illustrated in Fig. 10, the formation of ROS was significantly blunted in the presence of chelerythrine. Thus temsirolimus may induce oxidative stress in part by activation of protein kinase C. In contrast, temsirolimus induced DCFDA fluorescence was similar in the presence (from $19.1 \pm 0.5$ a.u. to $23.5 \pm 1.1$ a.u., $\mathrm{n}=24$ ) and in the absence (from $22.1 \pm 0.6$ a.u. to $24.6 \pm 1.5$ a.u., $\mathrm{n}=24$ ) of extracellular $\mathrm{Ca}^{2+}$.

Additional experiments explored whether the effect of temsirolimus on ceramide abundance was sensitive to chelerythrine and/or removal extracellular $\mathrm{Ca}^{2+}$. To this end, erythrocyte ceramide abundance was determined following incubation for 48 hours in the absence or presence of $20 \mu \mathrm{g} / \mathrm{ml}$ temsirolimus in the absence or presence of chelerythrine $(10 \mu \mathrm{M})$ and in the presence or nominal absence of $\mathrm{Ca}^{2+}$. As a result, the increase of ceramide dependent fluorescence in erythrocytes following temsirolimus was similar in the absence (from $10.6 \pm 0.3$ a.u. to $14.8 \pm 2.7$ a.u., $\mathrm{n}=6$ ) and in the presence (from $10.7 \pm 0.4$ a.u. to $15.1 \pm$ 2.6 a.u., $\mathrm{n}=6)$ of chelerythrine $(10 \mu \mathrm{M})$, as well as in the presence (from $10.9 \pm 0.1$ a.u. to 15.3 \pm 3.2 a.u., $\mathrm{n}=5$ ) and absence (from $12.1 \pm 0.4$ a.u. to $16.2 \pm 3.2$ a.u., $\mathrm{n}=5$ ) of extracellular $\mathrm{Ca}^{2+}$.

Temsirolimus $(20 \mu \mathrm{g} / \mathrm{ml})$ further increased the percentage of phosphatidylserine exposing erythrocytes to similar values following incubation in the absence (from $1.28 \pm$ $0.10 \%$ to $8.55 \pm 0.85 \%, \mathrm{n}=19$ ) and in the presence (from $1.22 \pm 0.07 \%$ to $7.85 \pm 1.22 \%$, $\mathrm{n}=19)$ of SB203580 $(2 \mu \mathrm{M})$. Temsirolimus $(20 \mu \mathrm{g} / \mathrm{ml})$ further increased the percentage of phosphatidylserine exposing erythrocytes to similar values following incubation in the absence (from $1.36 \pm 0.14 \%$ to $11.79 \pm 0.94 \%, \mathrm{n}=15$ ) and in the presence (from $0.90 \pm 0.03$ $\%$ to $10.07 \pm 1.28 \%, \mathrm{n}=15)$ of $\mathrm{D} 4476(10 \mu \mathrm{M})$.

To test whether the effects of temsirolimus involved caspases, the influence of temsirolimus on annexin-V-binding was tested in the presence of pancaspase inhibitor zVAD. As a result, temsirolimus $(20 \mu \mathrm{g} / \mathrm{ml})$ increased the percentage of phosphatidylserine exposing erythrocytes to similar values following incubation in the absence (from $1.19 \pm$ $0.12 \%$ to $10.51 \pm 0.98 \%, \mathrm{n}=5$ ) and in the presence (from $2.40 \pm 0.81 \%$ to $13.54 \pm 1.15 \%$, $\mathrm{n}=5)$ of $\mathrm{zVAD}(10 \mu \mathrm{M})$.

In order to explore the effect of temsirolimus on hemolysis, the percentage of hemolytic cells was quantified from the hemoglobin concentration in the supernatant. As illustrated in Fig. 11, a 48 hours exposure to temsirolimus increased the percentage of hemolytic erythrocytes, an effect reaching statistical significance at $20 \mu \mathrm{g} / \mathrm{ml}$ temsirolimus concentration.

\section{Discussion}

The present study uncovers a novel effect of temsirolimus, i.e. triggering of erythrocyte shrinkage and of erythrocyte cell membrane scrambling with phosphatidylserine translocation to the erythrocyte surface. Erythrocyte shrinkage and cell membrane scrambling are the hallmarks of eryptosis, the suicidal erythrocyte death.

The effect of temsirolimus on cell shrinkage and cell membrane scrambling was paralleled by an increase of cytosolic $\mathrm{Ca}^{2+}$ activity $\left(\left[\mathrm{Ca}^{2+}\right]_{\mathrm{i}}\right)$ and the cell membrane scrambling was blunted by removal of extracellular $\mathrm{Ca}^{2+}$. The cell shrinkage was at least in part due to increase 
of $\left[\mathrm{Ca}^{2+}\right]_{\mathrm{i}}$ with subsequent activation of $\mathrm{Ca}^{2+}$ sensitive $\mathrm{K}^{+}$channels, $\mathrm{K}^{+}$exit, cell membrane hyperpolarization, $\mathrm{Cl}^{-}$exit and thus cellular loss of $\mathrm{KCl}$ with water [61]. An increase of $\left[\mathrm{Ca}^{2+}\right]_{\mathrm{i}}$ is further known to stimulate a scramblase [61]. Comparison of the Figs. 1 and 2 with Fig. 3 would suggest, however that higher concentrations of temsirolimus are needed to increase $\left[\mathrm{Ca}^{2+}\right]_{\mathrm{i}}$ than those required to trigger cell shrinkage and cell membrane scrambling. More importantly, temsirolimus triggered cell membrane scrambling even in the nominal absence of extracellular $\mathrm{Ca}^{2+}$, an observation pointing to the involvement of additional mechanisms contributing to temsirolimus induced cell membrane scrambling. Temsirolimus treatment increased the ceramide abundance, which is known to sensitize erythrocytes for the scrambling effect of $\mathrm{Ca}^{2+}$ [61]. Moreover, temsirolimus significantly enhanced the abundance of reactive oxygen species, a well known trigger of eryptosis [61]. Temsirolimus is therefore partially effective by inducing oxidative stress. The effect of temsirolimus was significantly blunted by staurosporine and chelerythrine, an observation pointing to the involvement of protein kinase C. Protein kinase $\mathrm{C}$ participates for instance in the orchestration of eryptosis following hyperosmotic shock [61]. Apparently, chelerythrine further blunts the temsirolimus induced oxidative stress. The effect of temsirolimus on annexin V binding apparently does not require SB203580 sensitive p38 kinase, D4476 sensitive casein kinase 1, or zVAD sensitive caspases.

Phosphatidylserine exposing erythrocytes are rapidly cleared from circulating blood and stimulation of eryptosis may lead to anemia as soon as the loss of erythrocytes surpasses the formation of new erythrocytes by erythropoiesis [61]. The temsirolimus concentrations required for the stimulation of eryptosis are well in the range of concentrations (102 $\mu \mathrm{g} /$ $\mathrm{ml}$ ) encountered in the plasma of patients [60]. The stimulation of eryptosis may thus well explain the anemia following temsirolimus treatment $[59,60]$. Phosphatidylserine exposing erythrocytes further adhere to the vascular wall [152], stimulate blood clotting and trigger thrombosis [153-155], and may thus interfere with microcirculation [65, 153, 156-159]. Along those lines thrombosis has been observed in some patients receiving temsirolimus treatment $[160,161]$.

In conclusion, temsirolimus triggers eryptosis with erythrocyte shrinkage and erythrocyte cell membrane scrambling, an effect in part due to $\mathrm{Ca}^{2+}$ entry, oxidative stress, ceramide and staurosporine sensitive kinase(s).

\section{Acknowledgements}

The authors acknowledge the meticulous preparation of the manuscript by Lejla Subasic. The study was supported by the Deutsche Forschungsgemeinschaft, and the Open Access Publishing Fund of Tuebingen University.

\section{Disclosure Statement}

The authors of this manuscript declare that they have no conflicts of interests.

\section{References}

-1 Schulze M, Stock C, Zaccagnini M, Teber D, Rassweiler JJ: Temsirolimus. Recent Results Cancer Res 2014;201:393-403.

2 Bukowski RM: Temsirolimus: a safety and efficacy review. Expert Opin Drug Saf 2012;11:861-879.

-3 Peuvrel L, Quereux G, Brocard A, Saint-Jean M, Dreno B: Onychopathy induced by temsirolimus, a mammalian target of rapamycin inhibitor. Dermatology 2012;224:204-208.

4 Gomez-Fernandez C, Garden BC, Wu S, Feldman DR, Lacouture ME: The risk of skin rash and stomatitis with the mammalian target of rapamycin inhibitor temsirolimus: a systematic review of the literature and meta-analysis. Eur J Cancer 2012;48:340-346. 


\section{Cellular Physiology Cell Physiol Biochem 2017;42:1575-1591 \begin{tabular}{l|l} 
and Biochemistry DOI: 10.1159/000479398 2017 & $\begin{array}{l}\text { () } 2017 \text { The Author(s). Published by S. Karger AG, Basel } \\
\text { www.karger.com/cpb }\end{array}$ \\
\hline
\end{tabular}

5 De Masson A, Fouchard N, Mery-Bossard L, Dauendorffer JN: Cutaneous and mucosal aphthosis during temsirolimus therapy for advanced renal cell carcinoma: review of cutaneous and mucosal side effects of mTOR inhibitors. Dermatology 2011;223:4-8.

6 Stock C, Zaccagnini M, Schulze M, Teber D, Rassweiler JJ: Temsirolimus. Recent Results Cancer Res 2010;184:189-197.

7 Boni JP, Hug B, Leister C, Sonnichsen D: Intravenous temsirolimus in cancer patients: clinical pharmacology and dosing considerations. Semin Oncol 2009;36 Suppl 3:S18-25.

-8 Rini BI: Temsirolimus, an inhibitor of mammalian target of rapamycin. Clin Cancer Res 2008;14:12861290.

9 Ma WW, Jimeno A: Temsirolimus. Drugs Today (Barc) 2007;43:659-669.

10 Dreyling M, Jurczak W, Jerkeman M, Silva RS, Rusconi C, Trneny M, Offner F, Caballero D, Joao C, WitzensHarig M, Hess G, Bence-Bruckler I, Cho SG, Bothos J, Goldberg JD, Enny C, Traina S, Balasubramanian S, Bandyopadhyay N, Sun S, Vermeulen J, Rizo A, Rule S: Ibrutinib versus temsirolimus in patients with relapsed or refractory mantle-cell lymphoma: an international, randomised, open-label, phase 3 study. Lancet 2016;387:770-778.

11 Coiffier B: Clinical efficacy and management of temsirolimus in patients with relapsed or refractory mantle cell lymphoma. Clin Lymphoma Myeloma Leuk 2013;13:351-359.

12 Bouabdallah K, Ribrag V, Terriou L, Soria JC, Delarue R: Temsirolimus in the treatment of mantle cell lymphoma: frequency and management of adverse effects. Curr Opin Oncol 2013;25 Suppl 2:S1-12.

13 Hess G: Temsirolimus for the treatment of mantle cell lymphoma. Expert Rev Hematol 2009;2:631-640.

14 Hoy SM, McKeage K: Temsirolimus: In relapsed and/or refractory mantle cell lymphoma. Drugs 2010;70:1819-1829.

15 Hess G, Smith SM, Berkenblit A, Coiffier B: Temsirolimus in mantle cell lymphoma and other non-Hodgkin lymphoma subtypes. Semin Oncol 2009;36 Suppl 3:S37-45.

16 Dancey JE, Curiel R, Purvis J: Evaluating temsirolimus activity in multiple tumors: a review of clinical trials. Semin Oncol 2009;36 Suppl 3:S46-58.

17 Porta C, Tortora G, Larkin JM, Hutson TE: Management of poor-risk metastatic renal cell carcinoma: current approaches, the role of temsirolimus and future directions. Future Oncol 2016;12:533-549.

18 Zanardi E, Verzoni E, Grassi P, Necchi A, Giannatempo P, Raggi D, De Braud F, Procopio G: Clinical experience with temsirolimus in the treatment of advanced renal cell carcinoma. Ther Adv Urol 2015;7:152-161.

19 Afshar M, Pascoe J, Whitmarsh S, James N, Porfiri E: Temsirolimus for patients with metastatic renal cell carcinoma: outcomes in patients receiving temsirolimus within a compassionate use program in a tertiary referral center. Drug Des Devel Ther 2015;9:13-19.

20 Iacovelli R, Santoni M, Verzoni E, Grassi P, Testa I, de Braud F, Cascinu S, Procopio G: Everolimus and temsirolimus are not the same second-line in metastatic renal cell carcinoma. A systematic review and meta-analysis of literature data. Clin Genitourin Cancer 2015;13:137-141.

-21 Hutson TE, Escudier B, Esteban E, Bjarnason GA, Lim HY, Pittman KB, Senico P, Niethammer A, Lu DR, Hariharan S, Motzer RJ: Randomized phase III trial of temsirolimus versus sorafenib as second-line therapy after sunitinib in patients with metastatic renal cell carcinoma. J Clin Oncol 2014;32:760-767.

22 Payton S: Kidney cancer: Temsirolimus fails to expand its role in patients with mRCC. Nat Rev Urol 2014;11:2.

-23 Wong MK, Yang H, Signorovitch JE, Wang X, Liu Z, Liu NS, Qi CZ, George DJ: Comparative outcomes of everolimus, temsirolimus and sorafenib as second targeted therapies for metastatic renal cell carcinoma: a US medical record review. Curr Med Res Opin 2014;30:537-545.

24 Schrader AJ, Seseke S, Keil C, Herrmann E, Goebell PJ, Weikert S, Steffens S, Bergmann L, Roigas J, Steiner T: Temsirolimus in daily use: results of a prospective multicentre noninterventional study of patients with metastatic kidney cancer. Eur Urol 2014;66:275-281.

25 Stenner-Liewen F, Grunwald V, Greil R, Porta C: The clinical potential of temsirolimus in second or later lines of treatment for metastatic renal cell carcinoma. Expert Rev Anticancer Ther 2013;13:1021-1033.

26 Venugopal B, Ansari J, Aitchison M, Tho LM, Campbell R, Jones RJ: Efficacy of temsirolimus in metastatic chromophobe renal cell carcinoma. BMC Urol 2013;13:26.

27 Hadoux J, Vignot S, De La Motte Rouge T: Renal cell carcinoma: focus on safety and efficacy of temsirolimus. Clin Med Insights Oncol 2010;4:143-154. 


\section{Cellular Physiology Cell Physiol Biochem 2017;42:1575-1591 \begin{tabular}{ll|l} 
DOI: 10.1159/000479398 & O 2017 The Author(s). Published by S. Karger AG, Basel \\
www.karger.com/cpb
\end{tabular}

28 Maroto JP, Hudes G, Dutcher JP, Logan TF, White CS, Krygowski M, Cincotta M, Shapiro M, Duran I, Berkenblit A: Drug-related pneumonitis in patients with advanced renal cell carcinoma treated with temsirolimus. J Clin Oncol 2011;29:1750-1756.

29 Gerullis H, Ecke TH, Eimer C, Heuck CJ, Otto T: mTOR-inhibition in metastatic renal cell carcinoma. Focus on temsirolimus: a review. Minerva Urol Nefrol 2010;62:411-423.

-30 Mackenzie MJ, Rini BI, Elson P, Schwandt A, Wood L, Trinkhaus M, Bjarnason G, Knox J: Temsirolimus in VEGF-refractory metastatic renal cell carcinoma. Ann Oncol 2011;22:145-148.

-31 Kwitkowski VE, Prowell TM, Ibrahim A, Farrell AT, Justice R, Mitchell SS, Sridhara R, Pazdur R: FDA approval summary: temsirolimus as treatment for advanced renal cell carcinoma. Oncologist 2010;15:428435.

32 Norum J, Nieder C, Kondo M: Sunitinib, sorafenib, temsirolimus or bevacizumab in the treatment of metastatic renal cell carcinoma: a review of health economic evaluations. J Chemother 2010;22:75-82.

-33 Ravaud A, Bernhard JC, Gross-Goupil M, Digue L, Ferriere JM: [mTOR inhibitors: temsirolimus and everolimus in the treatment of renal cell carcinoma]. Bull Cancer 2010;97:45-51.

34 Guevremont C, Alasker A, Karakiewicz PI: Management of sorafenib, sunitinib, and temsirolimus toxicity in metastatic renal cell carcinoma. Curr Opin Support Palliat Care 2009;3:170-179.

35 Hudes GR, Berkenblit A, Feingold J, Atkins MB, Rini BI, Dutcher J: Clinical trial experience with temsirolimus in patients with advanced renal cell carcinoma. Semin Oncol 2009;36 Suppl 3:S26-36.

-36 Thompson Coon J, Hoyle M, Green C, Liu Z, Welch K, Moxham T, Stein K: Bevacizumab, sorafenib tosylate, sunitinib and temsirolimus for renal cell carcinoma: a systematic review and economic evaluation. Health Technol Assess 2010;14:1-184, iii-iv.

37 Bhatia S, Thompson JA: Temsirolimus in patients with advanced renal cell carcinoma: an overview. Adv Ther 2009;26:55-67.

-38 Parikh J, Coleman T, Messias N, Brown J: Temsirolimus in the treatment of renal cell carcinoma associated with Xp11.2 translocation/TFE gene fusion proteins: a case report and review of literature. Rare Tumors 2009;1:e53.

39 Le Tourneau C, Faivre S, Serova M, Raymond E: mTORC1 inhibitors: is temsirolimus in renal cancer telling us how they really work? Br J Cancer 2008;99:1197-1203.

40 Malizzia LJ, Hsu A: Temsirolimus, an mTOR inhibitor for treatment of patients with advanced renal cell carcinoma. Clin J Oncol Nurs 2008;12:639-646.

41 Figlin RA: Mechanisms of Disease: survival benefit of temsirolimus validates a role for mTOR in the management of advanced RCC. Nat Clin Pract Oncol 2008;5:601-609.

42 Simpson D, Curran MP: Temsirolimus: in advanced renal cell carcinoma. Drugs 2008;68:631-638.

43 Bhojani N, Jeldres C, Patard JJ, Perrotte P, Suardi N, Hutterer G, Patenaude F, Oudard S, Karakiewicz PI: Toxicities associated with the administration of sorafenib, sunitinib, and temsirolimus and their management in patients with metastatic renal cell carcinoma. Eur Urol 2008;53:917-930.

44 Gore ME: Temsirolimus in the treatment of advanced renal cell carcinoma. Ann Oncol 2007;18 Suppl 9:ix87-88.

-45 Abdel-Rahman 0, Fouad M: Risk of oral and gastrointestinal mucosal injury in patients with solid tumors treated with everolimus, temsirolimus or ridaforolimus: a comparative systematic review and metaanalysis. Expert Rev Anticancer Ther 2015;15:847-858.

-46 Bagatell R, Norris R, Ingle AM, Ahern C, Voss S, Fox E, Little AR, Weigel BJ, Adamson PC, Blaney S: Phase 1 trial of temsirolimus in combination with irinotecan and temozolomide in children, adolescents and young adults with relapsed or refractory solid tumors: a Children's Oncology Group Study. Pediatr Blood Cancer 2014;61:833-839.

47 Kang HG, Wang BZ, Zhang J, Liu MR, Li YX: Combination of temsirolimus and adriamycin exhibits an enhanced antitumor effect in hepatocellular carcinoma. Clin Res Hepatol Gastroenterol 2016;10.1016/j. clinre.2016.09.005

48 Vazakidou ME, Magkouta S, Moschos C, Psallidas I, Pappas A, Psarra K, Kalomenidis I: Temsirolimus targets multiple hallmarks of cancer to impede mesothelioma growth in vivo. Respirology 2015;20:1263-1271.

49 Zoellner AK, Weiglein T, Hutter G, Zimmermann Y, Cieplik HC, Hess G, Dreyling M: Temsirolimus acts as additive with bendamustine in aggressive lymphoma. Ann Hematol 2016;95:403-407.

50 Carew JS, Espitia CM, Zhao W, Mita MM, Mita AC, Nawrocki ST: Targeting Survivin Inhibits Renal Cell Carcinoma Progression and Enhances the Activity of Temsirolimus. Mol Cancer Ther 2015;14:1404-1413. 


\section{Cellular Physiology Cell Physiol Biochem 2017;42:1575-1591 \begin{tabular}{l|l} 
and Biochemistry DOI: 10.1159/000479398 2017 & $\begin{array}{l}\text { (c) } 2017 \text { The Author(s). Published by S. Karger AG, Basel } \\
\text { www.karger.com/cpb }\end{array}$ \\
\hline
\end{tabular}

51 Fleuren ED, Versleijen-Jonkers YM, Roeffen MH, Franssen GM, Flucke UE, Houghton PJ, Oyen WJ, Boerman OC, van der Graaf WT: Temsirolimus combined with cisplatin or bevacizumab is active in osteosarcoma models. Int J Cancer 2014;135:2770-2782.

52 Kaneko M, Nozawa H, Hiyoshi M, Tada N, Murono K, Nirei T, Emoto S, Kishikawa J, Iida Y, Sunami E, Tsuno NH, Kitayama J, Takahashi K, Watanabe T: Temsirolimus and chloroquine cooperatively exhibit a potent antitumor effect against colorectal cancer cells. J Cancer Res Clin Oncol 2014;140:769-781.

53 Pinto-Leite R, Arantes-Rodrigues R, Ferreira R, Palmeira C, Colaco A, Moreira da Silva V, Oliveira P, Lara Santos L: Temsirolimus improves cytotoxic efficacy of cisplatin and gemcitabine against urinary bladder cancer cell lines. Urol Oncol 2014;32:41.e11-22.

54 Sperling J, Ziemann C, Gittler A, Benz-Weisser A, Menger MD, Kollmar O: Hepatic arterial infusion of temsirolimus inhibits tumor growth of colorectal rat liver metastases even after a growth stimulating procedure like liver resection. J Surg Res 2013;185:587-594.

55 Mahalingam D, Medina EC, Esquivel JA, 2nd, Espitia CM, Smith S, Oberheu K, Swords R, Kelly KR, Mita MM, Mita AC, Carew JS, Giles FJ, Nawrocki ST: Vorinostat enhances the activity of temsirolimus in renal cell carcinoma through suppression of survivin levels. Clin Cancer Res 2010;16:141-153.

56 Gandhi M, Kuzel T, Lacouture M: Eosinophilic rash secondary to temsirolimus. Clin Genitourin Cancer 2009;7:E34-36.

57 Coulter DW, Wilkie MB, Moats-Staats BM: Inhibition of IGF-I receptor signaling in combination with rapamycin or temsirolimus increases MYC-N phosphorylation. Anticancer Res 2009;29:1943-1949.

-58 Jiang T, Yu JT, Zhu XC, Tan MS, Wang HF, Cao L, Zhang QQ, Shi JQ, Gao L, Qin H, Zhang YD, Tan L: Temsirolimus promotes autophagic clearance of amyloid-beta and provides protective effects in cellular and animal models of Alzheimer's disease. Pharmacol Res 2014;81:54-63.

-59 Xu J, Tian D: Hematologic toxicities associated with mTOR inhibitors temsirolimus and everolimus in cancer patients: a systematic review and meta-analysis. Curr Med Res Opin 2014;30:67-74.

60 Geoerger B, Kieran MW, Grupp S, Perek D, Clancy J, Krygowski M, Ananthakrishnan R, Boni JP, Berkenblit A, Spunt SL: Phase II trial of temsirolimus in children with high-grade glioma, neuroblastoma and rhabdomyosarcoma. Eur J Cancer 2012;48:253-262.

61 Lang E, Lang F: Mechanisms and pathophysiological significance of eryptosis, the suicidal erythrocyte death. Semin Cell Dev Biol 2015;39:35-42.

62 Lang PA, Kaiser S, Myssina S, Wieder T, Lang F, Huber SM: Role of Ca2+-activated K+ channels in human erythrocyte apoptosis. Am J Physiol Cell Physiol 2003;285:C1553-C1560.

63 Harrison HE, Bunting H, Ordway NK, Albrink WS: The Pathogenesis of the Renal Injury Produced in the Dog by Hemoglobin or Methemoglobin. J Exp Med 1947;86:339-356.

64 LaRocca TJ, Stivison EA, Mal-Sarkar T, Hooven TA, Hod EA, Spitalnik SL, Ratner AJ: CD59 signaling and membrane pores drive Syk-dependent erythrocyte necroptosis. Cell Death Dis 2015;6:e1773.

-65 Abed M, Towhid ST, Mia S, Pakladok T, Alesutan I, Borst O, Gawaz M, Gulbins E, Lang F: Sphingomyelinaseinduced adhesion of eryptotic erythrocytes to endothelial cells. Am J Physiol Cell Physiol 2012;303:C991999.

-66 Lau IP, Chen H, Wang J, Ong HC, Leung KC, Ho HP, Kong SK: In vitro effect of CTAB- and PEG-coated gold nanorods on the induction of eryptosis/erythroptosis in human erythrocytes. Nanotoxicology 2012;6:847856.

67 Maellaro E, Leoncini S, Moretti D, Del Bello B, Tanganelli I, De Felice C, Ciccoli L: Erythrocyte caspase-3 activation and oxidative imbalance in erythrocytes and in plasma of type 2 diabetic patients. Acta Diabetol 2013;50:489-495.

68 Bissinger R, Lang E, Ghashghaeinia M, Singh Y, Zelenak C, Fehrenbacher B, Honisch S, Chen H, Fakhri H, Umbach AT, Liu G, Rexhepaj R, Liu G, Schaller M, Mack AF, Lupescu A, Birnbaumer L, Lang F, Qadri SM: Blunted apoptosis of erythrocytes in mice deficient in the heterotrimeric G-protein subunit Galphai2. Sci Rep 2016;6:30925.

69 Zelenak C, Eberhard M, Jilani K, Qadri SM, Macek B, Lang F: Protein kinase CK1alpha regulates erythrocyte survival. Cell Physiol Biochem 2012;29:171-180.

70 Bhavsar SK, Gu S, Bobbala D, Lang F: Janus kinase 3 is expressed in erythrocytes, phosphorylated upon energy depletion and involved in the regulation of suicidal erythrocyte death. Cell Physiol Biochem 2011;27:547-556. 


\section{Cellular Physiology Cell Physiol Biochem 2017;42:1575-1591 \begin{tabular}{l|l} 
DOI: 10.1159/000479398 & O 2017 The Author(s). Published by S. Karger AG, Basel \\
www.karger.com/cpb
\end{tabular}}

Published online:

71 Klarl BA, Lang PA, Kempe DS, Niemoeller OM, Akel A, Sobiesiak M, Eisele K, Podolski M, Huber SM, Wieder T, Lang F: Protein kinase C mediates erythrocyte "programmed cell death" following glucose depletion. Am J Physiol Cell Physiol 2006;290:C244-253.

72 Gatidis S, Zelenak C, Fajol A, Lang E, Jilani K, Michael D, Qadri SM, Lang F: p38 MAPK activation and function following osmotic shock of erythrocytes. Cell Physiol Biochem 2011;28:1279-1286.

73 Foller M, Sopjani M, Koka S, Gu S, Mahmud H, Wang K, Floride E, Schleicher E, Schulz E, Munzel T, Lang F: Regulation of erythrocyte survival by AMP-activated protein kinase. Faseb j 2009;23:1072-1080.

74 Foller M, Feil S, Ghoreschi K, Koka S, Gerling A, Thunemann M, Hofmann F, Schuler B, Vogel J, Pichler B, Kasinathan RS, Nicolay JP, Huber SM, Lang F, Feil R: Anemia and splenomegaly in cGKI-deficient mice. Proc Natl Acad Sci U S A 2008;105:6771-6776.

75 Lang E, Bissinger R, Fajol A, Salker MS, Singh Y, Zelenak C, Ghashghaeinia M, Gu S, Jilani K, Lupescu A, Reyskens KM, Ackermann TF, Foller M, Schleicher E, Sheffield WP, Arthur JS, Lang F, Qadri SM: Accelerated apoptotic death and in vivo turnover of erythrocytes in mice lacking functional mitogen- and stressactivated kinase MSK1/2. Sci Rep 2015;5:17316.

76 Zelenak C, Foller M, Velic A, Krug K, Qadri SM, Viollet B, Lang F, Macek B: Proteome analysis of erythrocytes lacking AMP-activated protein kinase reveals a role of PAK2 kinase in eryptosis. J Proteome Res 2011;10:1690-1697.

77 Shaik N, Lupescu A, Lang F: Sunitinib-sensitive suicidal erythrocyte death. Cell Physiol Biochem 2012;30:512-522.

78 Lupescu A, Shaik N, Jilani K, Zelenak C, Lang E, Pasham V, Zbidah M, Plate A, Bitzer M, Foller M, Qadri SM, Lang F: Enhanced erythrocyte membrane exposure of phosphatidylserine following sorafenib treatment: an in vivo and in vitro study. Cell Physiol Biochem 2012;30:876-888.

79 Alzoubi K, Egler J, Abed M, Lang F: Enhanced Eryptosis Following Auranofin Exposure. Cell Physiol Biochem 2015;37:1018-1028.

-80 Bissinger R, Barking S, Alzoubi K, Liu G, Liu G, Lang F: Stimulation of Suicidal Erythrocyte Death by the Antimalarial Drug Mefloquine. Cell Physiol Biochem 2015;36:1395-1405.

81 Bissinger R, Bouguerra G, Stockinger K, Abbes S, Lang F: Triggering of Suicidal Erythrocyte Death by Topotecan. Cell Physiol Biochem 2015;37:1607-1618.

82 Bouguerra G, Aljanadi O, Bissinger R, Abbes S, Lang F: Embelin-Induced Phosphatidylserine Translocation in the Erythrocyte Cell Membrane. Cell Physiol Biochem 2015;37:1629-1640.

83 Bouguerra G, Bissinger R, Abbes S, Lang F: Stimulation of Eryptosis by Narasin. Cell Physiol Biochem 2015;37:1807-1816.

84 Briglia M, Fazio A, Faggio C, Laufer S, Alzoubi K, Lang F: Triggering of Suicidal Erythrocyte Death by Ruxolitinib. Cell Physiol Biochem 2015;37:768-778.

-85 Briglia M, Fazio A, Signoretto E, Faggio C, Lang F: Edelfosine Induced Suicidal Death of Human Erythrocytes. Cell Physiol Biochem 2015;37:2221-2230.

-86 Calabro S, Alzoubi K, Faggio C, Laufer S, Lang F: Triggering of Suicidal Erythrocyte Death Following Boswellic Acid Exposure. Cell Physiol Biochem 2015;37:131-142.

87 Egler J, Lang F: Licochalcone A Induced Suicidal Death of Human Erythrocytes. Cell Physiol Biochem 2015;37:2060-2070.

-88 Faggio C, Alzoubi K, Calabro S, Lang F: Stimulation of suicidal erythrocyte death by PRIMA-1. Cell Physiol Biochem 2015;35:529-540.

89 Fazio A, Briglia M, Faggio C, Alzoubi K, Lang F: Stimulation of Suicidal Erythrocyte Death by Garcinol. Cell Physiol Biochem 2015;37:805-815.

-90 Lang E, Jilani K, Bissinger R, Rexhepaj R, Zelenak C, Lupescu A, Lang F, Qadri SM: Vitamin D-Rich Diet in Mice Modulates Erythrocyte Survival. Kidney Blood Press Res 2015;40:403-412.

-91 Lang E, Zelenak C, Eberhard M, Bissinger R, Rotte A, Ghashghaeinia M, Lupescu A, Lang F, Qadri SM: Impact of Cyclin-Dependent Kinase CDK4 Inhibition on Eryptosis. Cell Physiol Biochem 2015;37:1178-1186.

$\$ 92$ Officioso A, Alzoubi K, Manna C, Lang F: Clofazimine Induced Suicidal Death of Human Erythrocytes. Cell Physiol Biochem 2015;37:331-341.

\$3 Peter T, Bissinger R, Enkel S, Alzoubi K, Oswald G, Lang F: Programmed erythrocyte death following in vitro Treosulfan treatment. Cell Physiol Biochem 2015;35:1372-1380.

-94 Stockinger K, Bissinger R, Bouguerra G, Abbes S, Lang F: Enhanced Eryptosis Following Exposure to Carnosic Acid. Cell Physiol Biochem 2015;37:1779-1791. 


\section{Cellular Physiology Cell Physiol Biochem 2017;42:1575-1591 \begin{tabular}{l|l} 
and Biochemistry Published online: July 21, 2017 & $\begin{array}{l}\text { D) } 2017 \text { The Author(s). Published by S. Karger AG, Basel } \\
\text { www.karger.com/cpb }\end{array}$ \\
\hline
\end{tabular}}

Al Mamun Bhuyan et al.: Temsirolimus-Induced Eryptosis

95 Waibel S, Bissinger R, Bouguerra G, Abbes S, Lang F: Saquinavir Induced Suicidal Death of Human Erythrocytes. Cell Physiol Biochem 2015;37:1973-1982.

-96 Zierle J, Bissinger R, Egler J, Lang F: Lapatinib Induced Suicidal Death of Human Erythrocytes. Cell Physiol Biochem 2015;37:2275-2287.

-97 Bissinger R, Bouguerra G, Al Mamun Bhuyan A, Waibel S, Abbes S, Lang F: Efavirenz Induced Suicidal Death of Human Erythrocytes. Cell Physiol Biochem 2015;37:2496-2507.

-98 Bissinger R, Waibel S, Bouguerra G, Al Mamun Bhuyan A, Abbes S, Lang F: Enhanced Eryptosis Following Exposure to Lopinavir. Cell Physiol Biochem 2015;37:2486-2495.

-99 Briglia M, Calabro S, Signoretto E, Alzoubi K, Laufer S, Faggio C, Lang F: Fucoxanthin Induced Suicidal Death of Human Erythrocytes. Cell Physiol Biochem 2015;37:2464-2475.

100 Briglia M, Fazio A, Faggio C, Lang F: Triggering of Suicidal Erythrocyte Death by Zosuquidar. Cell Physiol Biochem 2015;37:2355-2365.

101 Fazio A, Briglia M, Faggio C, Alzoubi K, Lang F: Oxaliplatin Induced Suicidal Death of Human Erythrocytes. Cell Physiol Biochem 2015;37:2393-2404.

102 Macczak A, Cyrkler M, Bukowska B, Michalowicz J: Eryptosis-inducing activity of bisphenol A and its analogs in human red blood cells (in vitro study). J Hazard Mater 2016;307:328-335.

103 Officioso A, Alzoubi K, Lang F, Manna C: Hydroxytyrosol inhibits phosphatidylserine exposure and suicidal death induced by mercury in human erythrocytes: Possible involvement of the glutathione pathway. Food Chem Toxicol 2016;89:47-53.

104 Officioso A, Manna C, Alzoubi K, Lang F: Bromfenvinphos induced suicidal death of human erythrocytes. Pestic Biochem Physiol 2016;126:58-63.

105 Qadri SM, Donkor DA, Bhakta V, Eltringham-Smith LJ, Dwivedi DJ, Moore JC, Pepler L, Ivetic N, Nazi I, Fox-Robichaud AE, Liaw PC, Sheffield WP: Phosphatidylserine externalization and procoagulant activation of erythrocytes induced by Pseudomonas aeruginosa virulence factor pyocyanin. J Cell Mol Med 2016;10.1111/jcmm.12778

106 Zierle J, Bissinger R, Bouguerra G, Abbes S, Lang F: Triggering of Suicidal Erythrocyte Death by Regorafenib. Cell Physiol Biochem 2016;38:160-172.

107 Pagano M, Faggio C: The use of erythrocyte fragility to assess xenobiotic cytotoxicity. Cell Biochem Funct 2015;33:351-355.

108 Al Mamun Bhuyan A, Bissinger R, Stockinger K, Lang F: Stimulation of Suicidal Erythrocyte Death by Tafenoquine. Cell Physiol Biochem 2016;39:2464-2476.

109 Al Mamun Bhuyan A, Signoretto E, Bissinger R, Lang F: Enhanced Eryptosis Following Exposure to Dolutegravir. Cell Physiol Biochem 2016;39:639-650.

110 Al Mamun Bhuyan A, Signoretto E, Lang F: Triggering of Suicidal Erythrocyte Death by Psammaplin A. Cell Physiol Biochem 2016;39:908-918.

-111 Almasry M, Jemaa M, Mischitelli M, Faggio C, Lang F: Stimulation of Suicidal Erythrocyte Death by Phosphatase Inhibitor Calyculin A. Cell Physiol Biochem 2016;40:163-171.

112 Bissinger R, Bhuyan AA, Signoretto E, Lang F: Stimulating Effect of Elvitegravir on Suicidal Erythrocyte Death. Cell Physiol Biochem 2016;38:1111-1120.

113 Egler J, Zierle J, Lang F: Stimulating Effect of Manumycin A on Suicidal Erythrocyte Death. Cell Physiol Biochem 2016;38:1147-1156.

114 Jemaa M, Mischitelli M, Fezai M, Almasry M, Faggio C, Lang F: Stimulation of Suicidal Erythrocyte Death by the CDC25 Inhibitor NSC-95397. Cell Physiol Biochem 2016;40:597-607.

115 Lang E, Pozdeev VI, Gatidis S, Qadri SM, Haussinger D, Kubitz R, Herebian D, Mayatepek E, Lang F, Lang KS, Lang PA: Bile Acid-Induced Suicidal Erythrocyte Death. Cell Physiol Biochem 2016;38:1500-1509.

116 Mischitelli M, Jemaa M, Almasry M, Faggio C, Lang F: Stimulation of Erythrocyte Cell Membrane Scrambling by Quinine. Cell Physiol Biochem 2016;40:657-667.

117 Mischitelli M, Jemaa M, Almasry M, Faggio C, Lang F: Stimulation of Suicidal Erythrocyte Death by Rottlerin. Cell Physiol Biochem 2016;40:558-566.

118 Mischitelli M, Jemaa M, Almasry M, Faggio C, Lang F: Triggering of Erythrocyte Cell Membrane Scrambling by Emodin. Cell Physiol Biochem 2016;40:91-103.

119 Mischitelli M, Jemaa M, Almasry M, Faggio C, Lang F: Triggering of Suicidal Erythrocyte Death by Fascaplysin. Cell Physiol Biochem 2016;39:1638-1647. 


\section{Cellular Physiology Cell Physiol Biochem 2017;42:1575-1591 \begin{tabular}{ll|l} 
and Biochemistry Published online: July 21, 2017 & $\begin{array}{l}\text { C } 2017 \text { The Author(s). Published by S. Karger AG, Basel } \\
\text { www.karger.com/cpb }\end{array}$
\end{tabular}}

Al Mamun Bhuyan et al.: Temsirolimus-Induced Eryptosis

120 Mischitelli M, Jemaa M, Almasry M, Faggio C, Lang F: Ca2+ Entry, Oxidative Stress, Ceramide and Suicidal Erythrocyte Death Following Diosgenin Treatment. Cell Physiol Biochem 2016;39:1626-1637.

121 Peter T, Bissinger R, Lang F: Stimulation of Eryptosis by Caspofungin. Cell Physiol Biochem 2016;39:939949.

122 Peter T, Bissinger R, Liu G, Lang F: Anidulafungin-Induced Suicidal Erythrocyte Death. Cell Physiol Biochem 2016;38:2272-2284.

123 Peter T, Bissinger R, Signoretto E, Mack AF, Lang F: Micafungin-Induced Suicidal Erythrocyte Death. Cell Physiol Biochem 2016;39:584-595.

124 Pretorius E, du Plooy JN, Bester J: A Comprehensive Review on Eryptosis. Cell Physiol Biochem 2016;39:1977-2000.

125 Shan F, Yang R, Ji T, Jiao F: Vitamin C Inhibits Aggravated Eryptosis by Hydrogen Peroxide in Glucose-6Phosphated Dehydrogenase Deficiency. Cell Physiol Biochem 2016;39:1453-1462.

126 Signoretto E, Bissinger R, Castagna M, Lang F: Stimulation of Eryptosis by Combretastatin A4 Phosphate Disodium (CA4P). Cell Physiol Biochem 2016;38:969-981.

127 Signoretto E, Castagna M, Al Mamun Bhuyan A, Lang F: Stimulating Effect of Terfenadine on Erythrocyte Cell Membrane Scrambling. Cell Physiol Biochem 2016;38:1425-1434.

128 Signoretto E, Castagna M, Lang F: Stimulation of Eryptosis, the Suicidal Erythrocyte Death by Piceatannol. Cell Physiol Biochem 2016;38:2300-2310.

129 Signoretto E, Honisch S, Briglia M, Faggio C, Castagna M, Lang F: Nocodazole Induced Suicidal Death of Human Erythrocytes. Cell Physiol Biochem 2016;38:379-392.

130 Signoretto E, Laufer SA, Lang F: Stimulating Effect of Sclareol on Suicidal Death of Human Erythrocytes. Cell Physiol Biochem 2016;39:554-564.

131 Signoretto E, Zierle J, Bissinger R, Castagna M, Bossi E, Lang F: Triggering of Suicidal Erythrocyte Death by Pazopanib. Cell Physiol Biochem 2016;38:926-938.

132 Wesseling MC, Wagner-Britz L, Huppert H, Hanf B, Hertz L, Nguyen DB, Bernhardt I: Phosphatidylserine Exposure in Human Red Blood Cells Depending on Cell Age. Cell Physiol Biochem 2016;38:1376-1390.

133 Zierle J, Bissinger R, Lang F: Inhibition by Teriflunomide of Erythrocyte Cell Membrane Scrambling Following Energy Depletion, Oxidative Stress and Ionomycin. Cell Physiol Biochem 2016;39:1877-1890.

134 Bissinger R, Modicano P, Alzoubi K, Honisch S, Faggio C, Abed M, Lang F: Effect of saponin on erythrocytes. Int J Hematol 2014;100:51-59.

135 Bissinger R, Modicano P, Frauenfeld L, Lang E, Jacobi J, Faggio C, Lang F: Estramustine-induced suicidal erythrocyte death. Cell Physiol Biochem 2013;32:1426-1436.

136 Lang E, Modicano P, Arnold M, Bissinger R, Faggio C, Abed M, Lang F: Effect of thioridazine on erythrocytes. Toxins (Basel) 2013;5:1918-1931.

137 Al Mamun Bhuyan A, Bissinger R, Cao H, Lang F: Triggering of Suicidal Erythrocyte Death by bexaroten. Cell Physiol Biochem 2016;in press.:

138 Abed M, Feger M, Alzoubi K, Pakladok T, Frauenfeld L, Geiger C, Towhid ST, Lang F: Sensitization of erythrocytes to suicidal erythrocyte death following water deprivation. Kidney Blood Press Res 2013;37:567-578.

139 Voelkl J, Alzoubi K, Mamar AK, Ahmed MS, Abed M, Lang F: Stimulation of suicidal erythrocyte death by increased extracellular phosphate concentrations. Kidney Blood Press Res 2013;38:42-51.

140 Abed M, Artunc F, Alzoubi K, Honisch S, Baumann D, Foller M, Lang F: Suicidal erythrocyte death in endstage renal disease. J Mol Med (Berl) 2014;92:871-879.

141 Ahmed MS, Langer H, Abed M, Voelkl J, Lang F: The uremic toxin acrolein promotes suicidal erythrocyte death. Kidney Blood Press Res 2013;37:158-167.

142 Polak-Jonkisz D, Purzyc L: Ca(2+) influx versus efflux during eryptosis in uremic erythrocytes. Blood Purif 2012;34:209-210; author reply 210.

143 Calderon-Salinas JV, Munoz-Reyes EG, Guerrero-Romero JF, Rodriguez-Moran M, Bracho-Riquelme RL, Carrera-Gracia MA, Quintanar-Escorza MA: Eryptosis and oxidative damage in type 2 diabetic mellitus patients with chronic kidney disease. Mol Cell Biochem 2011;357:171-179.

144 Lang PA, Beringer O, Nicolay JP, Amon O, Kempe DS, Hermle T, Attanasio P, Akel A, Schafer R, Friedrich B, Risler T, Baur M, Olbricht CJ, Zimmerhackl LB, Zipfel PF, Wieder T, Lang F: Suicidal death of erythrocytes in recurrent hemolytic uremic syndrome. J Mol Med (Berl) 2006;84:378-388. 


\section{Cellular Physiology Cell Physiol Biochem 2017;42:1575-1591 \begin{tabular}{l|l} 
DOI: 10.1159/000479398 & Ond 2017 The Author(s). Published by S. Karger AG, Basel \\
www.karger.com/cpb
\end{tabular}}

Al Mamun Bhuyan et al.: Temsirolimus-Induced Eryptosis

145 Nicolay JP, Schneider J, Niemoeller OM, Artunc F, Portero-Otin M, Haik G, Jr., Thornalley PJ, Schleicher E, Wieder T, Lang F: Stimulation of suicidal erythrocyte death by methylglyoxal. Cell Physiol Biochem 2006;18:223-232.

146 Bissinger R, Schumacher C, Qadri SM, Honisch S, Malik A, Gotz F, Kopp HG, Lang F: Enhanced eryptosis contributes to anemia in lung cancer patients. Oncotarget 2016;7:14002-14014.

147 Qadri SM, Mahmud H, Lang E, Gu S, Bobbala D, Zelenak C, Jilani K, Siegfried A, Foller M, Lang F: Enhanced suicidal erythrocyte death in mice carrying a loss-of-function mutation of the adenomatous polyposis coli gene. J Cell Mol Med 2012;16:1085-1093.

148 Bissinger R, Kempe-Teufel DS, Honisch S, Qadri SM, Randrianarisoa E, Haring HU, Henes J, Lang F: Stimulated Suicidal Erythrocyte Death in Arteritis. Cell Physiol Biochem 2016;39:1068-1077.

149 Lang PA, Schenck M, Nicolay JP, Becker JU, Kempe DS, Lupescu A, Koka S, Eisele K, Klarl BA, Rubben H, Schmid KW, Mann K, Hildenbrand S, Hefter H, Huber SM, Wieder T, Erhardt A, Haussinger D, Gulbins E, Lang F: Liver cell death and anemia in Wilson disease involve acid sphingomyelinase and ceramide. Nat Med 2007;13:164-170.

150 Lupescu A, Bissinger R, Goebel T, Salker MS, Alzoubi K, Liu G, Chirigiu L, Mack AF, Qadri SM, Lang F: Enhanced suicidal erythrocyte death contributing to anemia in the elderly. Cell Physiol Biochem 2015;36:773-783.

151 Lang E, Pozdeev VI, Xu HC, Shinde PV, Behnke K, Hamdam JM, Lehnert E, Scharf RE, Lang F, Haussinger D, Lang KS, Lang PA: Storage of Erythrocytes Induces Suicidal Erythrocyte Death. Cell Physiol Biochem 2016;39:668-676.

152 Borst O, Abed M, Alesutan I, Towhid ST, Qadri SM, Foller M, Gawaz M, Lang F: Dynamic adhesion of eryptotic erythrocytes to endothelial cells via CXCL16/SR-PSOX. Am J Physiol Cell Physiol 2012;302:C644-C651.

153 Andrews DA, Low PS: Role of red blood cells in thrombosis. Curr Opin Hematol 1999;6:76-82.

154 Chung SM, Bae ON, Lim KM, Noh JY, Lee MY, Jung YS, Chung JH: Lysophosphatidic acid induces thrombogenic activity through phosphatidylserine exposure and procoagulant microvesicle generation in human erythrocytes. Arterioscler Thromb Vasc Biol 2007;27:414-421.

155 Zwaal RF, Comfurius P, Bevers EM: Surface exposure of phosphatidylserine in pathological cells. Cell Mol Life Sci 2005;62:971-988.

156 Closse C, Dachary-Prigent J, Boisseau MR: Phosphatidylserine-related adhesion of human erythrocytes to vascular endothelium. Br J Haematol 1999;107:300-302.

157 Gallagher PG, Chang SH, Rettig MP, Neely JE, Hillery CA, Smith BD, Low PS: Altered erythrocyte endothelial adherence and membrane phospholipid asymmetry in hereditary hydrocytosis. Blood 2003;101:46254627.

158 Pandolfi A, Di Pietro N, Sirolli V, Giardinelli A, Di Silvestre S, Amoroso L, Di Tomo P, Capani F, Consoli A, Bonomini M: Mechanisms of uremic erythrocyte-induced adhesion of human monocytes to cultured endothelial cells. J Cell Physiol 2007;213:699-709.

159 Wood BL, Gibson DF, Tait JF: Increased erythrocyte phosphatidylserine exposure in sickle cell disease: flowcytometric measurement and clinical associations. Blood 1996;88:1873-1880.

160 Fleming GF, Filiaci VL, Marzullo B, Zaino RJ, Davidson SA, Pearl M, Makker V, Burke JJ, 2nd, Zweizig SL, Van Le L, Hanjani P, Downey G, Walker JL, Reyes HD, Leslie KK: Temsirolimus with or without megestrol acetate and tamoxifen for endometrial cancer: a gynecologic oncology group study. Gynecol Oncol 2014;132:585592.

161 Alvarez EA, Brady WE, Walker JL, Rotmensch J, Zhou XC, Kendrick JE, Yamada SD, Schilder JM, Cohn DE, Harrison CR, Moore KN, Aghajanian C: Phase II trial of combination bevacizumab and temsirolimus in the treatment of recurrent or persistent endometrial carcinoma: a Gynecologic Oncology Group study. Gynecol Oncol 2013;129:22-27. 